\title{
Effect of Jinfeicao Paste for External Application on Rat Sore Models
}

\author{
Ming BAI, Yan LI, Ting WANG, Yan ZHENG, Dandan LIU, MingSan MIAO* \\ Henan College of Traditional Chinese Medicine, Hennan Zhengzhou 450008, China
}

\begin{abstract}
Objective: To explore the effect of Jinfeicao paste for external application on rat sore models. Methods: Rat models of sores were established by staphylococcus aureus. To observe the symptom score, serum lysozyme content and pathological changes of rats with sores treated by low and high dose of Inula japonica Thunb (IP)and Inula linariifolia Turcz. (ITP).Results: High and low doses IP and ITP could could both reduce the symptom score of rats with sores, increase serum lysozyme content and improve pathological changes. Conclusion: Jinfeicao paste application hasremarkable curative effect on sores ulcers rats model.
\end{abstract}

KEYWORD: Jinfeicao paste; External application; rats; sores models.

\section{INTRODUCTION}

Jinfeicao is Asteraceae Compositae Inula linariifolia Turcz. or Inula japonica Thunb stem and leaf which is applied to clinical commonly traditional Chinese medicine (TCM) and treatment of respiratory diseases, liver fights, blood gas in addition to the full, breeze through intestinal guide, cold water to drink, Juan phlegm, and no injury of Yin, sweat and dry, clinical use of diseases such as cough cold often obtain good effect[1]. There is almost no research on Jinfeicao for external use only, but as a result of modern clinical indicated that inula hydrosols decoction has a cough, protect liver function, to staphylococcus aureus, herpes virus, streptococcus pneumoniae, pseudomonas aeruginosa, escherichia coli, bacillus anthracis has bacteriostatic action [2]. To explore the effect of Jinfeicao paste for external application on rat sore models. so this experiment by observing its effect on sore rat model, verification jinfeicao topical can promote the healing of wound infection of the power and the regulation of the external function.

\section{MATERIAL}

\subsection{Animals}

Wistar rat, male and female, Weight $180 \sim 220 \mathrm{~g}$, supplied by the Experimental Animal Center of Hebei Medical. Animal permit number: 1110123. Laboratory Certificate of Conformity: SYXK (Henan) 2010-001.

\subsection{Experimental reagents and drugs}

Jinfeicao, which collected from Baiyun Mountain in Henan Luoyang and by the Henan University of Traditional Chinese Medicine Department of Pharmacognosy identification of Compositae Inula linariifolia Turcz.and Inula japonica Thunb. To remove impurities, wash, cut, dried, and set aside.The Inula japonica Thunb paste preparation: fresh Inula $100 \mathrm{~g}$ water $150 \mathrm{~mL}$ machine crushing with food, goods $0.25 \mathrm{~g} \mathrm{~mL}^{-1}$ dry concentration of inula flower pretty, $100 \mathrm{~g}$ inula flower water $283 \mathrm{~mL}$ with food machine grinding, concentration of inula flower pretty dry goods $0.15 \mathrm{~g} \mathrm{~mL}^{-1}$. Which will as high, low dose of jinfeicao and the drug after filling cold storage; the fresh inula flower water content is 50\%; ITP preparation method with the same. Jingwanhong, Tianjin Darentang Jingwanhong Pharmaceutical Company Limited, production batch number 211717; Staphylococcus aureus (CMCC26003) provided by the henan college of traditional Chinese medicine microbiology laboratory; Sodium Chloride Injection, Henan Tailong pharmaceutical Limited by Share Ltd, production batch number 11082465; Formaldehyde, Yantai Shuangshuang Chemical Co. Ltd., production batch number 20100308; Qiaomier depilatory creams, Guangzhou Yibai Ya cosmetics Co., Ltd., production batch number 20110321; Lysozyme (LZM) test kit: Nanjing Jiancheng Biological Engineering Institute, production batch number 20111121. 


\subsection{The instrument}

Trace pipetting, Shanghai refinement biochemical reagents instrument co., LTD; MJ - 180 - b type mold incubator, Shanghai yuejin medical instrument factory; KCS LDZM - 80 vertical high-pressure sterilization pot, branded medical equipment factory in Shanghai.

\section{EXPERIMENTAL METHODS}

\subsection{Rat ulcer models and index test}

Wistar rat, male and female,Weight $180 \sim 220 \mathrm{~g}$. Before one day of the experiment will each rat right back hair removal, which covers an area of $3 \mathrm{~cm} \mathrm{x} 3$ $\mathrm{cm}$. The second day out of 10 random as the blank group (male and female), the other 60 rats (male and female) made sore model. After anesthesia in rats with sterile surgical blade draw a "ten" the character of incision in the hair removal parts $(1 \mathrm{~cm} \times 1 \mathrm{~cm})$, deep subcutaneous, if the wound bleeding, bleeding, pressurized with sterile cotton ball in each wound with syringe injection configured staphylococcus aureus bacteria liquid $0.5 \mathrm{~mL}$ (inoculated staphylococcus aureus on nutrient AGAR culture medium, in the mold after cultivation in $37{ }^{\circ} \mathrm{C}$ for $24 \mathrm{~h}$, remove the colony and a moderate amount of sterile sodium chloride injection grinding, made concentration of $5 \times 108 / \mathrm{mL}$ of staphylococcus aureus bacteria liquid), once a day, three days in a row, to a redness, swelling, tenderness around the wound, visible purulent secretion so far [3] . We will building successful 60 rats by ulcers criteria [4] (normal is 0 points, ulcers site mild redness and swelling, sore or have healing for 1 minute, ulcers parts around the swelling, scabby, moderate or pus scab, or small amounts of pus out to 2 points, ulcers parts around the severe swelling bulge, scabby, or pus scab, or small amounts of pus out for 3 points) and male and female principles were randomly divided into 6 groups, respectively in ulcers local coating high,low dose of Inula linariifolia Turcz. and Inula japonica Thunb paste group and the paste $(0.25$ $\mathrm{g}, \mathrm{mL}-1,0.15 \mathrm{~g}, \mathrm{~mL}-1$, the dose of $0.5 \mathrm{~mL} / \mathrm{cm} 2$ ), Beijing Wan Gong ointment ( $2 \mathrm{~mm}$ thickness, the dose of $0.05 \mathrm{~g} / \mathrm{cm} 2$ ), two groups of the blank group, model group were coated with $0.9 \%$ sodium chloride injection $(0.5 \mathrm{~mL} / \mathrm{cm} 2)$, coated area are $3 \mathrm{~cm} \times 3 \mathrm{~cm}$. Above groups are used two layers of gauze to cover after the treatment, cling film to cover tape after fixation. Every day keep ulcers parts in contact with the drug time 6 hours, after 6 hours, wash and $0.9 \%$ sodium chloride injection and drugs. Continuous dosing dosing 1 times a day, 12 days. During the treatment, in the cage to partition makes it have a separate space, so as to avoid rats lick each other drugs or bite wounds.
From the first day onwards medication every three days once reference points scoring assessment, observation of the wound healing, $1 \mathrm{~h}$ after the treatment of the 12 days, the rat eyeball blood about $3000 \mathrm{rpm}$ centrifugal $10 \mathrm{~min}$, the determination of serum lysozyme kit with lysozyme enzyme content, clipping sore skin lesions parts, fixed in $10 \%$ formalin solution, under paraffin-embedded sections, HE staining, microscopy rats healing skin sores extent [5-6].

\section{RESULTS}

Effect on ulcer in experimental rats are shown in Table 1

Table 1 Effect of Inula paste applying on positive rat Pyocutaneous model score

\begin{tabular}{|l|c|l|l|l|l|}
\hline \multirow{2}{*}{ Group } & \multirow{4}{*}{$\mathrm{N}$} & \multicolumn{4}{|l|}{ Ulcer symptoms after induced } \\
\cline { 3 - 7 } & & $3 \mathrm{~d}$ & $6 \mathrm{~d}$ & $9 \mathrm{~d}$ & $12 \mathrm{~d}$ \\
\hline Blank group & 10 & $\begin{array}{l}0.0 \pm 0.0 \\
* *\end{array}$ & $\begin{array}{l}0.0 \pm 0.0 \\
* *\end{array}$ & $\begin{array}{l}0.0 \pm 0.0 \\
* *\end{array}$ & $\begin{array}{l}0.0 \pm 0.0 \\
* *\end{array}$ \\
\hline Model group & 10 & $2.7 \pm 0.5$ & $2.6 \pm 0.5$ & $2.5 \pm 0.5$ & $2.0 \pm 0.5$ \\
\hline Jingwan hong group & 10 & $2.6 \pm 0.5$ & $2.4 \pm 0.5$ & $\begin{array}{l}1.6 \pm 0.7 \\
* *\end{array}$ & $\begin{array}{l}1.1 \pm 0.3 \\
* *\end{array}$ \\
\hline $\begin{array}{l}\text { High doses of IP } \\
\text { group }\end{array}$ & 10 & $2.6 \pm 0.5$ & $2.5 \pm 0.5$ & $\begin{array}{l}1.7 \pm 0.7 \\
* *\end{array}$ & $\begin{array}{l}1.2 \pm 0.4 \\
* *\end{array}$ \\
\hline $\begin{array}{l}\text { Low doses of IP } \\
\text { group }\end{array}$ & 10 & $2.6 \pm 0.5$ & $2.5 \pm 0.5$ & $2.0 \pm 0.7$ & $\begin{array}{l}1.4 \pm 0.7 \\
* *\end{array}$ \\
\hline $\begin{array}{l}\text { High doses of ITP } \\
\text { group }\end{array}$ & 10 & $2.6 \pm 0.5$ & $2.5 \pm 0.5$ & $\begin{array}{l}1.9 \pm 0.6 \\
*\end{array}$ & $\begin{array}{l}1.3 \pm 0.5 \\
* *\end{array}$ \\
\hline $\begin{array}{l}\text { Low doses of ITP } \\
\text { group }\end{array}$ & 10 & $2.6 \pm 0.5$ & $2.5 \pm 0.5$ & $2.0 \pm 0.8$ & $\begin{array}{l}1.4 \pm 0.7 \\
* *\end{array}$ \\
\hline
\end{tabular}

Note: Compared with the model group, $* \mathrm{P}<0.05, * * \mathrm{P}<0.01$

From table 1, Compared with the control group, model group 3,6,9,12 -day scores were significantly higher ( $\mathrm{P}<0.01)$, illustrate successful modeling; Compared with model group, high-doses of IP group and Jingwanhong group can significantly reduce the rat sores model pyogenic skin 9 days of score $(\mathrm{P}<0.01)$, large doses of ITP group can obviously reduce the skin of rat sore models 9 days of score ( $\mathrm{P}<0.05)$; high, low dose of IP, high, low dose ITP and Positive control group can significantly reduce the the skin of rat sore models 12 days of score $(\mathrm{P}<0.01)$.

Effect on rat serum lysozyme sore model are shown in Table 2

From table 2, Compared with the blank group, significantly lower serum lysozyme content model group ( $\mathrm{P}<0.01)$, illustrate successful model; with the model group, the high-dose, small dose IP group, high dose of ITP dose group and Jingwanhong group, can significantly increase serum lysozyme content sore model $(\mathrm{P}<0.01)$, low-dose ITP group significantly liter high serum lysozyme content sore model $(\mathrm{P}<0.05)$. 
Table 2 Affect gold boiling grass paste topical content of rat serum lysozyme positive sore model

\begin{tabular}{|l|c|l|}
\hline Group & $\mathrm{N}$ & Lysozyme content $(\mu \mathrm{g} / \mathrm{ml})$ \\
\hline Blank group & 10 & $111.5 \pm 38.2^{* *}$ \\
\hline Model group & 10 & $55.1 \pm 7.3$ \\
\hline Jingwanong group & 10 & $88.0 \pm 13.5^{* *}$ \\
\hline High doses of IP group & 10 & $84.8 \pm 14.4^{* *}$ \\
\hline Low doses of IP group & 10 & $79.0 \pm 11.7^{* *}$ \\
\hline High doses of ITP group & 10 & $82.2 \pm 14.3^{* *}$ \\
\hline Low doses of ITP group & 10 & $76.5 \pm 13.5^{*}$ \\
\hline
\end{tabular}

Note: Compared with the model group, $* \mathrm{P}<0.05$, $* * \mathrm{P}<0.01$

\section{Effect of change of pathology of rats}

The experimental rats were sore skin histopathological observation results: skin group blank visible thin squamous epithelium and stratum corneum, subcutaneous tissue, hair follicle and sebaceous gland rod no other abnormal changes were normal, photo 1 . The rats in the model group ulcer local skin tissue visible thin squamous epithelium and keratinized layer, the subcutaneous tissue showed a large number of inflammatory cells and dense swollen, hair follicle, hair rod and the sebaceous glands are subject to a certain degree of damage, photo 2; Jingwanhong group rat ulcer local skin tissue visible thicker keratinized squamous epithelium and a layer of subcutaneous tissue, hair follicle, hair rod and sebaceous glands is basic and normal, subcutaneous tissue visible in a few scattered inflammatory cell infiltration, photo 3; High doses of IP group rat ulcer local skin tissue visible thicker keratinized squamous epithelium and a layer of subcutaneous tissue, hair follicle, hair rod and sebaceous glands is basic and normal, subcutaneous tissue inflammatory cell infiltration amount of visible, photo 4; Low dose of IP group rat ulcer local skin tissue visible significantly increased thin squamous epithelium and stratum corneum, subcutaneous tissue, hair follicle and sebaceous gland most bar replaced by fibrous tissue, photo 5; High doses of ITP group rat ulcer local skin tissue visible ulcerated squamous epithelium and stratum corneum, subcutaneous tissue, hair follicle and sebaceous hair rod were destroyed and the damage to a certain extent, in some cases of subcutaneous tissue under visible cystic cavity has the big and small amounts of inflammatory cells, photo 6; Low doses of ITP paste group rat ulcer local skin tissue visible ulcerated squamous epithelium and diversification level defect, subcutaneous tissue, hair follicle and sebaceous hair rod are subject to different degrees of damage, we can see some inflammatory cell infiltration and necrosis of subcutaneous tissue, see photo 7 .
Table 3 Effect of Inula paste applying on positive rat Pyocutaneous model of local skin tissue morphology

\begin{tabular}{|c|c|c|c|c|c|}
\hline Group & $\mathrm{N}$ & - & + & ++ & +++ \\
\hline Blank group & 10 & 10 & 0 & 0 & 0 \\
\hline Model group & 10 & 0 & 0 & 8 & 2 \\
\hline $\begin{array}{c}\text { Jingwanong } \\
\text { group }\end{array}$ & 10 & 6 & 4 & 0 & 0 \\
\hline $\begin{array}{c}\text { High doses of } \\
\text { IP group }\end{array}$ & 10 & 5 & 5 & 0 & 0 \\
\hline $\begin{array}{c}\text { Low doses of } \\
\text { IP group }\end{array}$ & 10 & 3 & 2 & 5 & 0 \\
\hline $\begin{array}{c}\text { High doses of } \\
\text { ITP group }\end{array}$ & 10 & 3 & 4 & 3 & 0 \\
\hline $\begin{array}{c}\text { Low doses of } \\
\text { ITP group }\end{array}$ & 10 & 0 & 4 & 6 & 0 \\
\hline
\end{tabular}

"-" skin epithelial tissue integrity, subcutaneous tissue and hair follicles and other appendages are normal; "+" skin epithelial tissue defect, hair follicles and other adnexal damaged, a small amount of inflammatory cell infiltration; "+ +" epithelial tissue defect of skin, hair follicles and other appendages damage, formation or cystic fibrous tissue; "+ + +" skin epithelium defect, subcutaneous hair follicles and other appendages are damaged, the formation of a large number of inflammatory cell invasion or abscess.

From table 3, analysis by Ridit test, and the blank group than in model group, local skin appears sore pathological injury significantly $(\mathrm{P}<0.01)$, indicating a successful model; compared with the model group, high dose of IP group, high dose of ITP group and Jingwanhong group can improve significantly the local pathological changes in rat skin ulcer model $(\mathrm{P}<0.01)$; low dose of IP group, low dose of ITP group can obviously improve the local pathological changes in rat skin ulcer model $(\mathrm{P}<0.05)$.

\section{DISCUSSION}

The sore is disease of common clinical surgery, including all of the tumor and ulcer, ulcer, such as furuncle, boil and so on, has the characteristics of rapid onset, part of the illness is more serious etc.. After the wound infection, the formation of ulcer. "Hurt" in the skin, appear after infection, wound infection is relatively shallow, thin, so called "abscess". "Innovation" in the muscles, the infection after the pus and blood stasis is deep, accompanied by swelling and heat pain, so called "sore" [7]. This experiment adopts the method of infection of Staphylococcus aureus infection to make rat Pyocutaneous model, wound infection, were reduced food intake, prone less dynamic, tenderness, wound with purulent secretion, red, swelling, heat, pain and other symptoms of [8-9] appeared around the wound and ulcers, "Yang Syndrome" consistent.

In order to better estimate the efficacy of topical jinfeicao on skin wound, evaluation experiments were conducted on ulcer symptoms in rats, serum lysozyme and integral model of local change of organization form. Ulcer symptoms integral 
indicates the degree of the local damage of wound, reflect the drug for promoting wound healing capacity; lysozyme is nonspecific immunity constitute an important antimicrobial substances, widely exists in the normal body fluid and various secretory fluids, mainly synthesized by macrophages and release, lysozyme can stick peptide molecules in the cell wall hydrolytic bacteria, the loss of cells wall of death and disintegration, and play a role in resistance to infection, and improve the content, promote the increase of various complement, antibody, cellulose and bactericidal substance. Therefore, lysozyme is a reflection of an index of non-specific immune function[10-11], can objectively reflect the treatment of Inula on sore; local tissue pathology change can reflect the degree of the damaged tissue layers of skin inflammatory cell infiltration and healing, can directly reflect the drug efficacy. The sore model ulcer symptoms score, can be directly and objectively reflect the treatment effect of Inula sore model. Experimental results show that the high, low dose of Inula paste could significantly increase the content of lysozyme sore wound model, explain infection degree Jin jinfeicao can significantly improve the skin, promote healing of ulcer area; ulcer symptoms score results showed that before treatment 6D, no significant improvement of symptoms of sore, can obviously improve the symptoms of ninth days, Twelfth days of gold the stems and leaves of high dosage can significantly improve the symptoms of ulcer, the effects of low dosage of times; in effect on tissue of rat Pyocutaneous model pathology, Inula paste can promote ulcer repair tissue closure gap, reduce the infiltration of inflammatory cells, suggesting that Inula paste for external use has good healing sore myogenic effect, topical treatment of sore need time the accumulation of. This experiment jinfeicao paste detoxification eliminate sore external function provides the experimental basis, also provides a simple and effective treatment method for clinical treatment of pyogenic infection.

\section{REFERENCES}

[1] Wu HY, Wang JY. Inula clinical application experiences of. Chinese Journal of traditional Chinese medicine.2011, 26, (4): 746-748.

[2] He GY, Li G, Geng HM. Research progress of. Chinese medical innovation.2012, 9 inula flower (27): 161-163.

[3] Tang PP, Guo XF, Bai M, et al. Effect of Ampelopsis topical Pyocutaneous model. Chinese Journal of traditional Chinese medicine, 2012, 27 (3): 702-705.

[4] Miao MS, Zhang XX, Wu W. Polygala tenuifolia Decoction external effect on rat Pyocutaneous model. Chinese Journal of traditional Chinese medicine, 2014, 29 (9): 2772-2775.

[5] Miao MS,Tian S , Bai M, et al..Effect of Gardenia jasminoides Ellis powder for external application in mice

of sprain and contusion model. Moder Engineering Solution for the Industry, 2014; (4):1193

[6] Han XM, Luo YH, Shi YF. Study on the treatment of chronic ulcer of skin Pyocutaneous model test. Journal of Liaoning University of Traditional Chinese Medicine, 2009, 11 (5): 207-209.

[7] Zhang CC. To investigate the pathogenesis of ulcer. China herald of medicine, 2009,6 (7): 86

[8] Luo YH, Han XM, Chang FR, et al. Experimental study of Qufushengji ointment on the healing of rat model. Chinese medicine science and technology, 2002, 9 (5): 283-284.

[9] Miao MS, Cheng BL, Chen YP.Bitter almond oil puste external influence on rat guinea pig model of prurius. Moder Engineering Solution for the Industry, 2014; (4): 1343.

[10] Hao FM, Zhao QS, Ren XL, et al. Animal experimental study on Fuzheng detoxication mechanism supporting method. Chinese Journal of traditional Chinese medicine, 2010, 28 (7): 1418-1420.

[11] Yang JJ, Xie D. Effects of Shangyangyu ointment by experimental Staphylococcus aureus wound sore wound lysozyme content. Chinese Journal of hospital pharmacy, 2008, 28 (1): 78-79.

\section{APPENDIX}

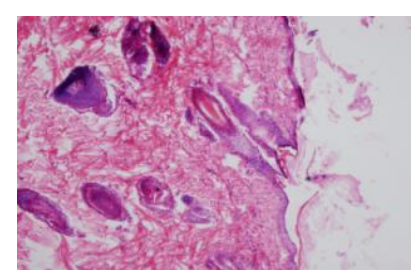

Photo 1 Blank group HE×100

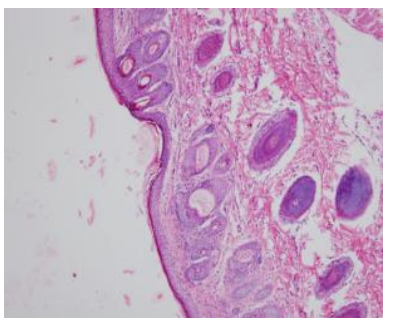

Photo 3 Jingwanhong groupHE×100

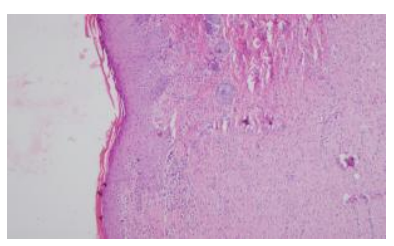

Photo 5Low doses of IP group HE×100

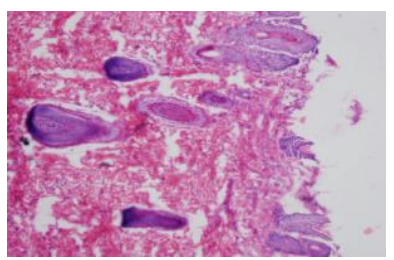

Photo 7 low doses of ITP group HE×100

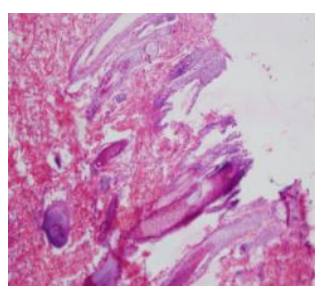

Photo2Model group HE×100

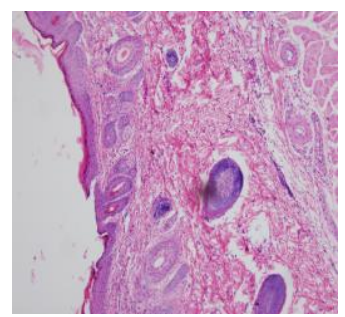

Photo 4 High doses of IPgroup $\mathrm{HE} \times 100$

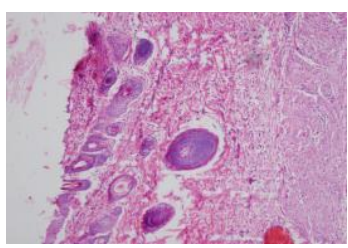

Photo6 High doses of ITPgroup HE×100 